\title{
Gabor Hellyer
}

\section{Assessing
Parliament's Response to the Covid-19 Pandemic}

\begin{abstract}
Parliament had to discharge its constitutional role in unprecedented conditions following the onset of the Covid-19 pandemic. How did it fare? This article assesses Parliament's response to the pandemic across its core constitutional functions of legislating, scrutinising, financing, representing and providing a government. It argues that Parliament's response was remarkably effective and resulted in meaningful permanent changes to the legislature's operation. Nonetheless, the response also highlighted opportunities for further institutional strengthening regarding Parliament's role in a national emergency.

Keywords Parliament, legislature, Epidemic Response Committee, scrutiny, accountability, legislation, national emergency, pandemic response
\end{abstract}

Gabor Hellyer is a Principal Clerk of Committee in Select Committee Services in the Office of the Clerk of the House of Representatives. Currently he clerks the Justice Committee, Privileges Committee, and Standing Orders Committee.
$\mathrm{E}$ ffective parliaments are fundamental to good quality democratic governance. Following the onset of the Covid-19 pandemic in early 2020, and during the first months in particular, Parliament had to discharge its constitutional functions in unprecedented circumstances. How did one of our oldest institutions, which is often considered slow to change and somewhat arcane, fare in adapting to the disruptions that left no part of society untouched?

This article examines the nature and quality of Parliament's response to the pandemic across its key functions of making and scrutinising legislation, scrutinising the executive, authorising and examining public expenditure, representing the people, and providing a government. It argues that Parliament's response was remarkably effective, driven by a culture of adaptability within established norms that has been purposively developed over recent decades. It touches briefly on the lasting legacy of Parliament's pandemic response, and identifies several opportunities for improving parliamentary effectiveness. 


\section{Focusing on constitutional functions}

To examine how Parliament performed, it is useful to focus on the institution's constitutional functions: legislating, scrutinising, financing, representing and providing a government. These roles are set out in McGee's Parliamentary Practice in New Zealand, except for financing. Financing is a composite of the legislating and scrutinising functions, separated here to highlight Parliament's constitutional role in public finance. Together, they describe the contribution Parliament is expected to make to democratic governance. ${ }^{1}$ They are described in more detail at the beginning of their respective sections below.

Our task is to examine the discharge of these functions through the lens of a major crisis. Naturally, success in a crisis will look different from success during normal times. At the same time, it is useful to keep in mind the extant standard to which each function has been performed. While variation should be expected, the development of substantively new expressions of key functions is a high expectation to place on a well-established institution responding to a crisis. Lastly, we should not expect Parliament to perform roles it is not designed to perform. Parliament's roles do not include, for example, being part of the operational response to an emergency. Rather, its role is to check the operational response through its scrutiny function, thereby making the response more effective. Before assessing the functions outlined above, it is helpful to outline a timeline of key events (see table above).

\section{Legislating: speed, delegation and ex post scrutiny}

Although Parliament is not the only body that makes law in New Zealand, it is the most important. Acts of Parliament set binding rules and frameworks in the form of statutory law, under which the executive can be delegated law-making powers and which the judicial branch can subsequently interpret. Emergencies often test existing rules and frameworks with novel and unexpected scenarios, and Covid-19 has been no different. So how effectively did Parliament perform its legislative role? On what criteria can this be assessed?

Timeline of key parliamentary events relating to Covid-19 in 2020

\begin{tabular}{|c|c|}
\hline 12 February & $\begin{array}{l}\text { First mention of Covid-19 in Parliament - minister of health delivers } \\
\text { a ministerial statement on the response to the virus. }\end{array}$ \\
\hline 3 March & $\begin{array}{l}\text { Minister of health delivers a ministerial statement on the first } \\
\text { case in New Zealand (confirmed on } 28 \text { February) and the nascent } \\
\text { response. }\end{array}$ \\
\hline 17 and 18 March & $\begin{array}{l}\text { Business Committee's first and second meetings to discuss } \\
\text { Parliament's response to the pandemic, including proposal for a } \\
\text { special epidemic committee. }\end{array}$ \\
\hline 19 March & $\begin{array}{l}\text { Temporary rule changes, agreed in principle at Business Committee, } \\
\text { are approved by the House. }{ }^{2} \text { The speaker issues rules allowing } \\
\text { remote participation of members in select committee meetings. }\end{array}$ \\
\hline 24 March & $\begin{array}{l}\text { Third meeting of Business Committee on Parliament's response, } \\
\text { including agreement to set up Epidemic Response Committee. }\end{array}$ \\
\hline 25 March & $\begin{array}{l}\text { Parliament recalled from planned one-week adjournment and } \\
\text { passes urgent Covid-19 legislation and establishes the Epidemic } \\
\text { Response Committee, then adjourns for four weeks ahead of alert } \\
\text { level } 4 \text { lockdown. }\end{array}$ \\
\hline 31 March & First meeting of Epidemic Response Committee during lockdown. \\
\hline 28 April & $\begin{array}{l}\text { The House sits for first time since } 25 \text { March - prime minister } \\
\text { delivers a statement on move to alert level } 3 \text { and ongoing state of } \\
\text { national emergency, and question time is held. }\end{array}$ \\
\hline 26 May & $\begin{array}{l}\text { Epidemic Response Committee disestablished after } 24 \text { meetings, } \\
\text { with opposition from the opposition. }\end{array}$ \\
\hline 16 June & First sitting of the House under alert level 1. \\
\hline 4 August & $\begin{array}{l}\text { Permanent changes to standing orders (Parliament's rules) adopted } \\
\text { by the House as part of regular triennial review, some with genesis } \\
\text { in pandemic response. }\end{array}$ \\
\hline 6 August & $\begin{array}{l}\text { Parliament holds 'adjournment debate', expecting to dissolve on } \\
12 \text { August. }\end{array}$ \\
\hline 18 August & $\begin{array}{l}\text { Parliament sits again following a delay to dissolution caused by } \\
\text { Covid-19 outbreak in Auckland and a subsequent delay to the date } \\
\text { of the general election. }\end{array}$ \\
\hline 2 September & Parliament meets for the last time before dissolution. \\
\hline 6 September & Parliament is dissolved. \\
\hline
\end{tabular}

The legislature has a tricky balance to strike in an emergency. On the one hand, it needs to be responsive and not unduly hinder the timeliness of response. On the other hand, it needs to ensure that good process and practice are not altogether dispensed with in addressing the exigencies of the day. It must also avoid its outputs departing markedly from the usual standards of quality. For example, fundamental rights must not be unjustifiably curtailed in the haste of crisis, and the laws made should be coherent. Finally, the legislature should at some point turn its mind to post-emergency thinking, reflecting on its law-making experiences and tidying up where necessary. And this is to say nothing of its extant, preemergency legislative programme.

First, some statistics. Between 25 March and 6 September 2020, a total of 58 bills were passed by the House. Of these, 14 were explicitly Covid-19-related. The House considered 51 bills under urgency, including nine that bypassed the select committee stage. Urgency accounted for $41.3 \%$ of the 253 hours of sitting time over this period. By comparison, urgency accounted for only $10.9 \%$ of the total sitting hours for the whole of the 52nd Parliament - up from $7.5 \%$ in the 51 st Parliament, but still far below the average of $20.5 \%$ between 1996 and 2011. Urgency in 2020 accounted for $62 \%$ of all urgency during the 52nd Parliament. ${ }^{3}$

The New Zealand Parliament has been known for its capacity to pass laws quickly. Indeed, this was evident in the response to Covid-19. Not all of this fast law making relied on urgency, however. The House can also set aside usual process 'by leave of the House' - that is, lack of a dissenting voice among the members present in the debating chamber. In practice, this is often agreed in advance at the Business Committee. ${ }^{4}$ The House granted such leave on 25 March and 
30 April to pass three Covid-19 bills through all legislative stages. Similarly, in response to a different crisis, the House passed the Canterbury Earthquake Response and Recovery Act 2010 through all stages by leave on 14 September 2010.

So, Parliament legislated promptly, and was not an undue barrier to addressing needs to change the law. However, this did not entail adaptation, and was to be expected. Of more interest is that some significant legislation was passed incredibly quickly and without select committee scrutiny - most notably, the Covid-19 Public Health Response Act 2020. The legislation was referred to a select committee for review after its passage, which was a welcome response to public criticism (see, for example, Geddis, 2020a). But the time allowed for scrutiny was relatively short, and the referral relied on the initiative of the government moving a motion in the House. It was sent to the Finance and Expenditure Committee, on which the majority of members were from parties in government, although its subject matter would arguably have sat better with the Epidemic Response Committee. Even so, the referral shows the force of parliamentary norms. Norms are an important if intangible component of institutions, and the ex post referral should be seen in this light. Notably, however, none of the other bills that bypassed select committee were referred for ex post scrutiny.

Parliament also passed the wrong version of a bill under urgency. Members were debating a draft of the bill circulated in advance, but a different version was delivered to the debating chamber in error. The bill in the chamber is always the authoritative version of what the House is debating. More than anything, this episode underscores the risks of legislating at breakneck speed. The error sprang from idiosyncratic arrangements between the Parliamentary Counsel Office, which drafts and prints most bills, and Inland Revenue, the only department that drafts its own bills (see Justice Committee, 2020a, pp.5-6). The fact that the error was not picked up during the parliamentary process was a direct consequence of truncating normal procedures. The government said the practical effect was simply that its planned small business loan scheme was legislated

\section{... although the law making was at times speedy and made more sparing use of the rear-view mirror than it might have, the resulting legislation did not raise widespread concern}

for sooner than intended (Coughlan, 2020), but it was an instructive experience nonetheless.

More important is the quality of the law that was made. Although some concerns were raised in the public sphere - particularly concerning the Covid-19 Public Health Response Act - there was no general opprobrium over the legislative response's inconsistency with fundamental constitutional principles (Knight, 2020). This contrasts with the response to the 2010 Canterbury earthquake, which led 27 experts in constitutional law to pen an open letter to 'New Zealand's people and their Parliament' expressing 'deep concern' over the legislative response (Geddis et al., 2010). So, although the law making was at times speedy and made more sparing use of the rear-view mirror than it might have, the resulting legislation did not raise widespread concern.

The concerns in the 2010 open letter all related to the extent and nature of the delegation of law-making power from Parliament to the executive. This is a key aspect of legislative quality, particularly in an emergency when there is a heightened need to respond to new and rapidly evolving operational challenges.

In fact, Parliament excelled in the realm of delegated legislation during the response to Covid-19. More specifically, the Regulations Review Committee performed particularly well.
The Regulations Review Committee is, by convention, chaired by an opposition member. It is tasked with advising other select committees on Parliament's delegation of law-making power to the executive, and overseeing the executive's use of its delegated powers. It discharged this crucial and often unseen scrutiny meticulously. Between 15 April and 5 August 2020, the committee examined prospective delegation powers in 11 bills and scrutinised 110 instruments made by the executive in response to Covid-19 (Regulations Review Committee, 2020). It is worth noting that a large amount of legislative power sat with the executive branch already, flowing from existing delegations on the statute book. This included both emergency-specific powers, such as those in the Epidemic Preparedness Act 2006, and regular regulation-making powers. As evidenced by the Regulations Review Committee's scrutiny, the government used these powers extensively.

While the Regulations Review Committee's work made few headlines, it made a real and significant contribution. It did so at times by working constructively with departments, ministers and other committees on areas for improvement. In many cases, regulations were amended in response to its scrutiny, and the committee reported that the quality of regulations increased significantly over time (ibid., p.3). At other times, the committee simply satisfied itself - and by extension the wider system and the public - that public power was being properly exercised.

In its fifth and final report on its Covid-19 review work, ${ }^{5}$ the Regulations Review Committee assessed Parliament's legislative response against the principles articulated by a previous iteration of the committee in a 2016 report on the response to the Canterbury earthquakes. It found that the principles deduced through that inquiry - doctrines of minimalism and safeguards, and an immediate focus on recovery - had been largely and satisfactorily observed in responding to Covid-19 (ibid., pp.12-13).

Overall, Parliament performed its legislative role successfully during the pandemic. However, the following improvements could be considered.

First, legislation passed quickly during an emergency - whether under urgency 
moved by the government or by leave of the House-should be subject to mandatory post-legislative scrutiny by a select committee, to ensure its immediate fitness for purpose and provide a guaranteed opportunity for public input. Doing so should not rely on the initiative of the government of the day. Rather, it should be specified in Parliament's rules. This would properly recognise Parliament's responsibility to ensure the quality of the laws it passes, even during an emergency. Such rules could include an expedited parliamentary process for legislative amendments recommended by the committee during such a review.

Second, the Regulations Review Committee scrutinises delegated legislation from a technical perspective only, focusing on whether the executive is using its delegated powers as Parliament intended and in line with constitutional principles concerning delegated legislation. ${ }^{6}$ Parliament should consider creating a structured process for assessing the policy content of delegated legislation made in response to an emergency. It is proper to delegate extensive legislative power during an emergency, but Parliament should also scrutinise whether the decisions made by the executive are justified. To a certain extent this is what the Epidemic Response Committee was tasked with doing, but it was essentially ad hoc, and the committee tended to focus on politically salient topics. A more structured process involving all subject select committees would increase the extent of legislative scrutiny, provide guaranteed avenues for opposition parties to probe the government's response, and increase the focus on less publicly prominent issues.

\section{Scrutinising: the role and effectiveness of the Epidemic Response Committee}

Scrutiny lies at the heart of almost all parliamentary activity. It is the fundamental mode by which Parliament contributes to the quality of governance. As described by Boston, Bagnall and Barry,

Scrutiny is the process of probing, considering and expressing views about the government's policy, expenditure and performance. The overall objectives are to promote better governance,

\section{The less theatrical, more informal setting of the virtual committee room proved better suited to probing governmental decisions on complex topics.}

maintain public confidence in the country's administration and ultimately secure the legitimacy of democratic institutions. (Boston, Bagnall and Barry, 2019, p.63)

This is more important than ever during an emergency. Yet many of the usual ways of conducting scrutiny are ill-suited to the pace of emergency governance. Parliamentary scrutiny is an interlinked system of reporting requirements, procedural triggers, information gathering and political debate. Its operation generally spans months rather than days. So how did Parliament fare in discharging this constitutional function during the pandemic?

Parliament's most significant adaptation to Covid-19 was the creation of the Epidemic Response Committee. Established ahead of the move to alert level 4 and the consequent four-week adjournment of the House, it was designed to conduct the scrutiny that would usually occur in the House. It was a resounding, if not uncomplicated, success. More than any other change, it demonstrated Parliament's ability to quickly adapt its workings to new realities, and capitalise afterwards on the experience gained.

The Epidemic Response Committee was established on a government motion in the House on 25 March 2020. This followed advice from the clerk of the House to the Business Committee and discussion over several meetings, and eventual agreement, of that committee.
Members from parties not in government constituted a majority on the Epidemic Response Committee, and it was chaired by the leader of the opposition. It was also given the rare power to summons documents and persons. The combination of these features alone mark it out as a significant moment in Parliament's history.

The committee met remotely by videoconference three days a week, the same number of days the House sits in a sitting week. Remote committee meetings were another major Covid-19 innovation, applicable to all select committees. Initially, the Epidemic Response Committee heard from ministers and senior public servants, before focusing more on hearings with business and community leaders. It received independent expert advice from a prominent epidemiologist, and considered two Covid-19 bills. Its meetings were broadcast on free-to-air Parliament TV - another first for select committees and streamed through a number of web platforms, attracting an unprecedented public viewership. The technical solutions to enable these features were devised and implemented at incredible speed in challenging circumstances by the agencies supporting Parliament.

The committee's style of scrutiny was notably different from question time. Hearings with ministers were significantly longer, more conversational, and judged to be genuinely informative. The less theatrical, more informal setting of the virtual committee room proved better suited to probing governmental decisions on complex topics. Credit is due for both the opposition's questioning and the government's engagement with the committee. As expressed by members during the debate on the committee's establishment, there was a genuine sense that it was there to 'work in the best interests of all New Zealanders' (Brownlee, 2020).

A more stringent assessment of the committee's contribution might require demonstrating its impact on policy. Such impact is a dimension of good scrutiny (Boston, Bagnall and Barry, 2019, p.74), but is difficult to assess on such a compact timeline. Also, focusing too narrowly on policy impact would miss the more indirect contributions that scrutiny makes. Simply knowing that decisions must run the 
gauntlet of parliamentary scrutiny helps instil discipline. And the public can take confidence from seeing scrutiny conducted, even if the direct effect on decision making is at times opaque.

Indeed, the committee had a significant impact on public engagement. It is nearimpossible to know how many tuned in to its meetings, due to the plethora of ways the public could watch (including many platforms not controlled by parliamentary agencies). The Epidemic Response Committee racked up over 3 million views on Parliament's Facebook and Vimeo channels, but it is estimated that this only accounts for 10-20\% of all viewership. Research by Colmar Brunton showed that one quarter of all New Zealanders had watched or listened to Parliament's select committees since the beginning of lockdown - a six-fold increase on earlier numbers (Colmar Brunton, 2020). Moreover, the reach of the committee was much higher than direct viewership, as its proceedings frequently appeared in the news media during lockdown. In short, Parliament successfully made itself relevant at a time when public attention was captivated by the pandemic and the operational response to it.

This impact is significant. As Boston, Bagnall and Barry note, 'Ensuring public confidence in the governance of the country is one of the main aims of the scrutiny process' (Boston, Bagnall and Barry, p.69). This is particularly true when the government is exercising significant powers, and asking the public to comply with unprecedented restrictions. Parliament, through the Epidemic Response Committee, performed particularly strongly on this count.

The committee was not without contentious moments. Ministers were instructed not to accept invitations from the committee following the resumption of sittings of the House (Small, 2020). Its positive contributions were eventually overshadowed somewhat by a politically fractious battle over its summonsing of legally privileged advice to the government (see Geddis, 2020b; Edgeler and Geddis, 2020). And, ultimately, it was disestablished on a government motion that both opposition parties opposed (Woodhouse, 2020).

\section{... Parliament should seriously consider creating permanent rules governing the creation and termination of a committee to scrutinise the government during extraordinary} times.

Yet the committee's brief tenure had a lasting and significant impact. In the 2020 review of Parliament's rules, the Standing Orders Committee strongly encouraged ministers to appear before select committees more often on legislation and the results of spending. In recommending this change, the Standing Orders Committee said the Epidemic Response Committee's 'model of more conversational scrutiny was widely seen as successful and there would be great merit' in more of it (Standing Orders Committee, 2020). Given that ministers generally attend select committee only once a year for hearings on the Budget, this could lead to a significant - and some might say overdue - rebalancing between the executive and the legislature.

The Epidemic Response Committee was a highly effective adaptation of Parliament's scrutiny function. However, the truth is that its existence was dependent on the will of the government - as evidenced by its disestablishment and attendant political disagreement. This is perhaps unsurprising in a parliamentary system, where the government must command a majority in the House. Having said this, we must also acknowledge the real and tangible respect for parliamentary norms evinced by its creation (see, for example, Hipkins, 2020).

Nonetheless, Parliament should seriously consider creating permanent rules governing the creation and termination of a committee to scrutinise the government during extraordinary times. They could hinge, for example, on whether certain statutory emergency powers have been invoked by the government. Such a committee should have an opposition majority. Without such rules, the legislature's institutional response to future emergencies would continue to depend on governing parties' view of Parliament's role. Well-designed institutions ensure the operation of their basic functions independent of the nature of the individuals who inhabit them.

\section{Financing: authorisation granted, examinations pending}

The government cannot levy taxes or spend public money without express authorisation from Parliament. Parliament is thus engaged in a continual cycle of scrutinising spending plans, approving the financing of the government, and examining the past performance and current operations of entities funded with public money.

On 25 March 2020 the House passed the Imprest Supply (Third for 2019/20) Bill. ${ }^{7}$ This authorised the government to spend up to $\$ 52$ billion on top of the $\$ 129.5$ billion authorised in Budget 2019 and the second imprest supply bill - an eyewateringly large figure. Budget 2020, introduced on 14 May, authorised just over $\$ 130$ billion in spending, which was later topped up with the largest-ever imprest supply of $\$ 56.6$ billion (Controller and Auditor-General, 2020). These figures represent the maximum spending authorised, and actual spending in 2019/20 is likely to be significantly lower. ${ }^{8}$ But they reflect the magnitude of the economic shock to New Zealand generated by the pandemic, and the level of uncertainty over how expensive the response will be.

The authorisation of spending is relatively permissive in New Zealand's unicameral Parliament. The real action is often in the backward-looking scrutiny, examining what has been achieved with the money spent by the government. In this 
regard, the 2019/20 annual review process - taking place in the first half of 2021 - will be a key test for Parliament's scrutiny of Covid-19-related spending.

In the meantime, much of the scrutiny is occurring in the 'institutional' layer (Boston, Bagnall and Barry, 2019, pp.645), often overlooked in the MP-centric idea of Parliament. The controller and auditor-general, as an officer of Parliament, discharges invaluable scrutiny of the government's spending. As public watchdog, the auditor-general's office has provided regular updates on the government's Covid-19 spending, undertaken a review of the management of personal protective equipment, and announced that it is reviewing the management of the wage subsidy scheme. ${ }^{9}$ Through this work, the auditorgeneral has and will continue to be a core part of the legislative branch's response to Covid-19.

Lastly, Parliament adopted a technical rule change to facilitate its work on financial scrutiny that ended up having a transformative effect beyond financial bills: the removal of the four-call limit. Previously, the standing orders limited the number of speeches MPs could make during a particular part of the legislative process called 'the committee stage, ${ }^{10}$ and capped their length at five minutes. The debate on annual reviews of public entities, during which MPs can question ministers, is technically the committee stage of a bill. As a result, members had grown used to making a small number of five-minute speeches.

The annual review debate took place under alert level 3 in 2020. This entailed a reduction in the number of members in the debating chamber. As described by the minister of finance when moving the motion to remove the four-call limit, there was a desire to ensure that the reduction in members present did not lead to a reduction of scrutiny. The focus on interactive debate and dialogue between ministers and opposition members generated by the Epidemic Response Committee provided further impetus for change: the limit's removal would facilitate members speaking more frequently, but for a shorter time. The hope was that this would lead to more questioning and better scrutiny, and less obligatory speech-making.
The most essential feature of our system of government is that representatives are elected to represent the views of the
people.

The change had a substantial impact. Following a much-improved annual review debate, the approach was continued for the remainder of the Parliament for other bills. In recommending the permanent removal of the limit in the triennial review of Parliament's rules, the Standing Orders Committee said the committee stage had been 'transformed very suddenly, and is much more satisfactory and enlightening' (Standing Orders Committee, 2020, p.40). Members paid tribute to the change in the House, including the prime minister when speaking on the election of the speaker on the first day of the 53rd Parliament (Ardern, 2020).

The limit's removal had been discussed previously, but had never quite arrived. It took adaptation to a pandemic to open the doors of possibility, leading to a permanent improvement to the legislative process.

\section{Representing: articulating in public,} assisting in private

Much like scrutiny, representing is fundamental to much of what happens at Parliament. The most essential feature of our system of government is that representatives are elected to represent the views of the people. While some rituals of representation are more salient than others, MPs are constantly representing the views of their electors. Additionally, select committees provide opportunities for direct public involvement in Parliament's proceedings.
Assessing representation is a complex and at times subjective task. For the purposes of this article, a handful of observations can be made on the discharge of this function during the pandemic response.

First, the Epidemic Response Committee provided a remarkable platform for the visible representation of different views, as well as for direct participation by organisations representing various sectors of society. However, the committee was criticised over a lack of Māori voices (Hurihanganui, 2020).

Second, many select committees continued to meet remotely during alert levels 4 and 3, hearing evidence from the public via videoconference on various issues. The Justice Committee, for example, heard over 20 hours of evidence from 86 submitters on proposed changes to restore the right to vote to certain prisoners. This was not without controversy, with opposition members and some members of the public objecting to non-Covid-19 legislation being progressed during the lockdown (Justice Committee, 2020b). However, it illustrates that the public continued to be represented even while they and their representatives were largely confined to their homes.

Lastly, MPs worked tirelessly in their electorates to assist their constituents remotely. A huge swell of enquiries followed the move to alert level 4, and MPs and their staff had to respond in challenging circumstances. MPs' constituent work is often largely unseen, but it was nearinvisible when conducted remotely.

\section{Providing a government: a question of confidence}

Our system requires that the government maintain the confidence of the House. This function receives little attention in the New Zealand context, because our Parliament is remarkably successful at providing governments. One point is worth mentioning, however.

Much was made by some commentators of the fact that the House was adjourned for the four weeks of alert level 4, casting it as an unprecedented disarming of Parliament. Several points should be weighed in considering this view.

First, the four-week adjournment included an already planned two-week 
adjournment for the school holidays. The additional two weeks does not seem extreme, particularly when compared to the four-five months for which Parliament frequently stood adjourned as recently as the mid-1980s.

Second, scrutiny was provided by the Epidemic Response Committee. As described above, this was arguably superior to the scrutiny that would have been conducted in the House. It would be incorrect to suggest that the executive was unchecked during this time. Given the general predominance the government enjoys over the House's agenda in our parliamentary system, the Epidemic Response Committee increased the opposition's agenda-setting power considerably.

Third, it is true that during this period the House was unable to express no confidence in the government. Had one of the governing parties sought to bring down the government through the withdrawal of confidence, the country would have faced a major constitutional crisis during a once-in-one-hundredyears public health crisis. Speculation over how the fall of the government during lockdown would have played out would be just that, speculation.

On balance, the supposed constitutional risk posed by adjourning Parliament for four weeks does not appear to warrant the hyperbole it attracted from some commentators.

\section{Factors influencing success}

Taken together, the changes adopted by Parliament demonstrate a significant capacity for innovation within established norms. Why was Parliament able to respond so successfully?

First, the Business Committee has emerged over the past decade as an invaluable cross-party forum for discussing and agreeing on how Parliament will operate. Every parliamentary party is entitled to representation and the committee makes decisions based on 'near unanimity' - objections from one smaller party may not be enough to stop a decision, but the speaker, in chairing the committee, must ensure its decisions do not unduly oppress the interests of smaller parties. All of this is specified in Parliament's rules (standing orders 77 and 78, House of
The Business Committee and the Standing Orders Committee are, in their current incarnations, creatures of the MMP era.

Representatives, 2020, p.22). The committee has significant powers to arrange the business of the House, and has also emerged as a forum for discussing temporary rule changes that require a motion in the House.

Similarly, there is a strong convention of consensus-based decision making for permanent changes to Parliament's rules through the Standing Orders Committee's triennial review of standing orders. Many of the changes trialled during the pandemic response were made permanent in the 2020 review. Few overseas parliaments have a comparable tradition.

More important, perhaps, than the existence of these mechanisms and their institutional design is the culture of mutual trust and respect fostered through their practical operation over time. Trust can only be built through repeated interactions. Just as trust was shown to be a defining feature of New Zealand's overall pandemic response (Standing Orders Committee, 2020, p.4), so too was it a key component of Parliament's response.

The Business Committee and the Standing Orders Committee are, in their current incarnations, creatures of the MMP era. Without the adaptation to multi-party parliaments engendered by MMP, the winner-takes-all culture generated by firstpast-the-post may well have weighed against the enhancement of Parliament's effectiveness.

\section{Conclusion}

The response to the Covid-19 pandemic during 2020 will leave a lasting legacy for New Zealand's parliamentary system of government, through select committees meeting virtually, more frequent scrutiny of ministers, better legislative processes, and, hopefully, more public engagement with Parliament. The Standing Orders Committee acknowledged this legacy in its 2020 report:

While the Covid-19 pandemic has considerably curtailed the available time and focus for the review of Standing Orders this year, it has resulted in many adaptations and innovations at Parliament, as it has across the community. ... The pandemic has strengthened the case for democratic institutions to continuously improve and become more effective, responsive, and accountable. Parliaments and Governments must attentively foster their legitimacy in the eyes of the public, so these institutions can appropriately contribute to a national response in times of crisis. (ibid., pp.4-5)

The pandemic response also highlighted two contrasting but complementary truths. On the one hand, cross-party consensus on adaptations and permanent changes revealed a striking political consensus over the role and value of Parliament. The force of parliamentary norms should not be underestimated. As overseas experiences with democratic deconsolidation demonstrate, norms and their maintenance are just as important as the written rules.

On the other hand, some of the best aspects of the response relied on the government of the day taking the initiative to enable them. Parliament, through the Business Committee, came up with its own response to the pandemic. But the government still had to move the motions to give effect to key aspects of the response.

We should take this opportunity to build on the successes of the response and further strengthen the institution of Parliament. After all, effective parliaments are fundamental to good quality democratic governance. A strong and active Parliament is in all New Zealanders' interests. 
1 Parliament and the House of Representatives are distinct entities, with the latter a component part of the former, together with the sovereign or her representative, the governor-general. However, reflecting lay usage, the term Parliament is used to refer to both here.

2 Not all procedural changes are described in this article. For example, certain previously paper-based requirements were altered to facilitate digital processes. For a further account of the changes made by Parliament, see Wilson, (2021).

3 Statistics for 52nd Parliament calculated using data from the Office of the Clerk. Other statistics drawn from Clerk of the House of Representatives, 2016.

4 For more information on the Business Committee, see section titled 'Factors influencing success'.

5 It is important to note that the Regulations Review Committee continues to scrutinise and report on delegated legislation made in response to Covid-19. The 'fifth and final' descriptor refers to the series of reports released between May and August 2020.

6 Two such principles that the committee raised concerns about were unclear drafting and inappropriate sub- delegation of delegated powers.

7 Imprest supply refers to interim legal authority to spend more than previously authorised. The first imprest supply of the financial year provides authority to spend in the period between the start of the financial year and the passing of the Budget in August/September. The second imprest supply is usually passed at the same time as the Budget, providing an update on the amounts estimated in May. A third imprest supply is uncommon, and addresses unforeseen circumstances ahead of the passage of the next financial year's Budget.

8. Since writing, the Government's audited financia statements have been released. Total expenditure for 2019.20 was $\$ 138.9$ billion.

9 For more information, see Controller and Auditor-General, 2020.

10 Not to be confused with the select committee stage, the committee stage involves the House turning itself into a 'committee of the whole House', with a different presiding officer (a chairperson rather than the speaker) and set of procedures, to debate amendments on the details of legislation. This takes place after the second reading debate and before the third reading debate. See Harris and Wilson (eds), 2017, pp.425-6.

\section{Acknowledgements}

I have benefited from discussions with many inspiring colleagues in preparing this article - thank you to you all. I am particularly grateful for feedback on the article from David Wilson, Pavan Sharma, Hans Landon-Lane, Tara Elmes and Victoria Corner, and research assistance from Pleasance Purser.

\section{References}

Ardern, J. (2020) 'Election of Speaker', New Zealand Parliamentary Debates, vol.749, 25 November, https://www.parliament.nz/en/pb/hansard-debates/rhr/combined/ HansD_20201125_20201125

Boston, J., D. Bagnall and A. Barry (2019) Foresight, Insight, and Oversight: enhancing long-term governance through better parliamentary scrutiny, Wellington: Institute for Governance and Policy Studies, https://www.victoria.ac.nz/_ data/assets/pdf file/001 1/1753571/Foresight-insight-and-oversight.pdf

Brownlee, G. (2020) 'Epidemic Response Committee', New Zealand Parliamentary Debates, vol.745, 25 March, https://www.parliament.nz/resource/en-NZ/HansD_20200325_20200 325/38d3fabdc0378c7f23f64fc95bb0d2521885d20b

Clerk of the House of Representatives (2016) Submission to Review of Standing Orders 2017, November, https://www.parliament.nz/resource/en-NZ/51SCSO_EVI_OODBSCH_ OTH_71094_1_A540680/3ad7268502a87dc0bb718fc99ba85a46b e955f49

Colmar Brunton (2020) 'Research on audiences for select committees', June, https://www.parliament.nz/en/footer/about-us/parliamentaryengagement/engagement-research/research-on-audiences-for-selectcommittees-june-2020/

Controller and Auditor-General (2020) 'Controller update on government spending on Covid-19', 17 September https://oag.parliament.nz/ media/2020/controller-september

Coughlan, T. (2020) 'Parliament passes the wrong law in an afternoon of urgent lawmaking', Stuff, 1 May, https://www.stuff.co.nz/national/300002365/parliament-passes-thewrong-law-in-an-afternoon-of-urgent-lawmaking

Edgeler, G. and A. Geddis (2020) 'The power(lessness) of New Zealand's House of Representatives to summon the Crown's legal advice', Public Law Review, 31, pp.229-33

Geddis, A. (2020a) 'The level two law is necessary - and full of flaws', Spinoff, 14 May, https://thespinoff.co.nz/politics/14-05-2020/ andrew-geddis-the-level-two-law-is-necessary-and-full-of-flaws/

Geddis, A. (2020b) 'Yes, the courts should scrutinise the lockdown. But Bridges' committee should back off', Spinoff, 7 May, https://thespinoff.co.nz/politics/07-05-2020/yes-the-courts-shouldscrutinise-the-lockdown-but-bridges-committee-should-back-off/

Geddis, A. et al. (2010) 'An open letter to New Zealand's people and their Parliament', Pundit, 28 September, https://www.pundit.co.nz/content/ an-open-letter-to-new-zealands-people-and-their-parliament

Harris, M. and D. Wilson (eds) (2017) Parliamentary Practice in New Zealand, 4th edn, Auckland: Oratia Media Ltd
Hipkins, C. (2020) 'Epidemic Response Committee', New Zealand Parliamentary Debates, vol.745, 25 March, https://www.parliament. nz/resource/en-NZ/HansD_20200325_20200325/38d3fabdc0378c7f 23f64fc95bb0d2521885d20b

House of Representatives (2020) Standing Orders of the House of Representatives, Wellington: House of Representatives

Hurihanganui, T.A. (2020) 'Simon Bridges ignored proposals for Māori at Epidemic Response Committee, MP says', RNZ, May, https://www.rnz. co.nz/news/te-manu-korihi/415943/simon-bridges-ignored-proposalsfor-maori-at-epidemic-response-committee-mp-says

Justice Committee (2020a) Report on 2020/21 Estimates for Vote Attorney-General and Vote Parliamentary Counsel, Wellington: House of Representatives, July, https://www.parliament.nz/resource/en-NZ/ SCR_99582/dc180b69d53d9039e511bf62e1d11fdcce89c1d1

Justice Committee (2020b) Report on Electoral (Registration of Sentenced Prisoners) Amendment Bill, Wellington: House of Representatives, May, https://www.parliament.nz/resource/en-NZ/SCR_97964/ a501b1133611df92b9f1d06f88849efef212499e

Knight, D. (2020) 'New Zealand, Covid-19 and the constitution: an effective lockdown and muted rule of law concerns', in Covid-19 and Constitutional Law, Universidad Nacional Autónoma de México, https:// archivos.juridicas.unam.mx/www/bjv/libros/13/6310/30a.pdf

Regulations Review Committee (2020) Final Report on the Briefing to Review Secondary Legislation Made in Response to Covid-19, Wellington: House of Representatives, August, https://www.parliament. nz/resource/en-NZ/SCR_99950/96a4c27af89de8a3e6abbfa9556684 $39 f c 3 d a 7 c$

Small, Z. (2020) 'Jacinda Ardern defends letter telling ministers to avoid Covid-19 Epidemic Response Committee', Newshub, 20 May, https:// www.newshub.co.nz/home/politics/2020/05/jacinda-ardern-defendsletter-telling-ministers-to-avoid-covid-19-epidemic-responsecommittee.html

Standing Orders Committee (2020) Review of Standing Orders 2020, Wellington: House of Representatives, July, https://www. parliament.nz/ resource/en-NZ/SCR_99753/ b30fe8b13213d753d48e0e3a0074056a7af787a5

Wilson, D. (2021) 'How the New Zealand Parliament responded to Covid-19', in Parliaments and the Pandemic, London: Study of Parliament Group

Woodhouse, M. (2020) 'Epidemic Response Committee’, New Zealand Parliamentary Debates, vol.745, 26 May, https://www.parliament.nz/ resource/en-NZ/HansD_20200526_20200526/595414c64a502d21 7a681017babe006dbec46f7b 